\title{
ENVIRONMENTAL INFLUENCE ON THE EGG SIZE OF PULLETS IN PUERTO RICO
}

\section{A. González Chapel and M. Rojas ${ }^{1}$}

\section{INTRODUCTION}

The study of the fluctuation in the curve of egg size for pullets in Puerto Rico is interesting when considered as part of the general evaluation of the effect of the tropical environment on egg production. González Chapel and Rojas $(3)^{2}$ had already observed an important influence of the time of hatching on the sexual maturity of a similar group of pullets in Puerto Rico.

The depressive effect of high temperatures on egg size has been reported by some workers in the United States. Bennion and Warren (1) found that the mean weekly egg weight when compared with the mean maximum weekly temperature showed a sharp decline when the temperature was above $85^{\circ} \mathrm{F}$. The mean daily egg size of birds placed under controlled temperature was reduced 15 or 20 percent by high temperatures. The egg size declined much more rapidly under high temperature than it increased when the temperature was lowered. Warren (8)' secured data on egg size from 11 localities in latitudes extending from the Equator to as far north as Scotland and concluded that excessively low temperatures seemed to have no effect on egg size, but after the daily maximum temperatures had exceeded $70^{\circ} \mathrm{F}$. for a few days, egg-size fluctuations usually showed a close correlation with those of temperature. Lorenz and Almquist (6) found evidence of a decrease in egg weight proportional to the increase in temperature between $40^{\circ}$ and $90^{\circ} \mathrm{F}$.

The average temperature in Puerto Rico is relatively uniform, the mean annual temperature being $76^{\circ}$, with an average minimum annual temperature of $66.9^{\circ}$ and an average maximum annual temperature of $86^{\circ} \mathrm{F}$. (4).

\section{Experimental Methods}

This study was made at the La Plata Animal Production Substation of the Agricultural Experiment Station; included in it were 206 pullets which laid throughout 1947-48. The breeds represented were the New Hampshire, with 124 birds; the White Leghorn, with 27 birds; and crossbreds of New Hampshire $\mathrm{x}$ Native and White Leghorn $\mathrm{x}$ Native, identified as Lines 1, 3, 5 , and 6 , with 51 birds. The birds were distributed in 18 groups according

${ }^{1}$ Associate Animal Husbandman and Assistant Animal Husbandman, respectively, Agricultural Experiment Station, University of Puerto Rico, Río Piedras, P. R.

${ }^{2}$ Numerals in parentheses refer to Literature Cited, page 120-21. 
to the month in which they started laying. These groups were as follows: New Hampshire-August, September, October, November, December, January; White Leghorn-August, September, November; Line 1-August October, November; Line 3-August; Line 5-August, September, November; Line 6-November, December.

Line 1 and Line 5 birds were New Hampshire $\mathrm{x}$ Native crossbreds and Line 3 and Line 6 birds were White Leghorn x Native crossbreds.

Of these 18 groups only 15 were considered in the statistical analysis. The other 3 groups-Line 5 in November, Line 1 in August, and White Leghorn

$\mathrm{T}_{\mathrm{ABLE}}$ 1.-Monthly average egg size in ounces per dozen for New Hampshire birds which were of different ages at sexual maturity and started laying

in different months

\begin{tabular}{|c|c|c|c|c|c|c|}
\hline \multirow{2}{*}{ Month birds started to lay } & \multicolumn{6}{|c|}{ Egg size in ounces per dozen for- } \\
\hline & $\begin{array}{l}9 \text { birds, } \\
\text { sexual } \\
\text { maturity } \\
\text { at } 182.4 \\
\text { days }\end{array}$ & $\begin{array}{c}37 \text { birds, } \\
\text { sexual } \\
\text { maturity } \\
\text { at } 190.9 \\
\text { days }\end{array}$ & $\begin{array}{l}26 \text { birds, } \\
\text { sexual } \\
\text { maturity } \\
\text { at } 22.9 .9 \\
\text { days }\end{array}$ & $\begin{array}{c}23 \text { birds, } \\
\text { sexual } \\
\text { maturity } \\
\text { at } 233.1 \\
\text { days }\end{array}$ & $\begin{array}{c}14 \text { birds, } \\
\text { sexual } \\
\text { maturity } \\
\text { at } 274.5 \\
\text { days }\end{array}$ & $\begin{array}{c}15 \text { birds, } \\
\text { sexual } \\
\text { maturity } \\
\text { at 301.2 } \\
\text { days }\end{array}$ \\
\hline August.. & 18.01 & & & & & \\
\hline September.......... & 19.29 & 18.11 & & & & \\
\hline October............... & 20.29 & 19.49 & 19.76 & & & \\
\hline November......... & 21.27 & 20.30 & 20.55 & 20.38 & & \\
\hline December........... & 21.90 & 20.85 & 21.40 & 21.07 & 21.42 & \\
\hline January............. & 22.26 & 21.66 & 21.70 & 21.66 & 22.15 & 21.70 \\
\hline February.. & 22.55 & 21.86 & 22.01 & 21.96 & 22.25 & 22.05 \\
\hline March............ & 22.84 & 22.05 & 22.38 & 22.24 & 22.65 & 22.43 \\
\hline April............ & 22.47 & 21.83 & 22.02 & 22.05 & 22.59 & 22.00 \\
\hline May.............. & 22.54 & 21.82 & 22.39 & 22.38 & 22.79 & 22.22 \\
\hline June.............. & 23.59 & 22.26 & 22.81 & 22.69 & 23.94 & 22.46 \\
\hline July............. & 23.74 & 22.31 & 22.50 & 22.19 & 22.97 & 22.87 \\
\hline August............. & & 22.46 & 23.20 & 23.20 & 23.53 & 23.46 \\
\hline September......... & & & 21.94 & 22.53 & 22.68 & 21.59 \\
\hline October........ & & & & 21.31 & 21.06 & 20.38 \\
\hline November...... & & & & & 21.31 & 21.38 \\
\hline December.......... & & & & & & 19.80 \\
\hline
\end{tabular}

in November, were not included because the variation between the months of laying was smaller than the variation between the birds within the month.

Egg size was measured by the weight of the eggs in ounces per dozen. The average egg size during each month was considered a good sample of the potentiality of the bird in respect to egg size for the particular month, regardless of the production during the month. Thus, for the regression studies, 12 average measures of egg size were taken per bird, starting with the first month of laying in each group and up to the twelfth month thereafter. 
TABLE 2.-Monthly average egg size in ounces per dozen for White Leghorn birds which were of different ages at sexual maturity and started laying in different months

\begin{tabular}{|c|c|c|}
\hline \multirow{2}{*}{ Month birds started to lay } & \multicolumn{2}{|c|}{ Egg size in ounces per dozen for - } \\
\hline & $\begin{array}{c}5 \text { birds, sexual maturity } \\
\text { at } 182.6 \text { days }\end{array}$ & $\begin{array}{c}17 \text { birds, sexual maturity } \\
\text { at } 184.4 \text { days }\end{array}$ \\
\hline August............... & 17.49 & \\
\hline September............. & 18.47 & 17.79 \\
\hline October................. & 19.73 & 18.84 \\
\hline November............... & 20.25 & 19.05 \\
\hline December............... & 21.86 & 20.29 \\
\hline January................ & 21.86 & 20.83 \\
\hline February $\ldots \ldots \ldots \ldots \ldots$ & 22.32 & 21.12 \\
\hline March................. & 22.05 & 21.40 \\
\hline April $\ldots \ldots \ldots \ldots \ldots \ldots \ldots$ & 22.06 & 20.67 \\
\hline May................... & 21.85 & 20.73 \\
\hline June.................. & 22.56 & 21.79 \\
\hline July................ & 22.32 & 21.34 \\
\hline August................ & & 22.20 \\
\hline
\end{tabular}

TABLE 3.-Monthly average egg size in ounces per dozen for birds of Lines 1, 3, 5, and 6 which were of different sexual maturity and started laying in different months

[Numerals in boldfaced type indicate month birds started laying]

\begin{tabular}{|c|c|c|c|c|c|c|}
\hline \multirow[b]{2}{*}{ Month } & \multicolumn{6}{|c|}{ Egg size in ounces per dozen for - } \\
\hline & $\begin{array}{l}9 \text { birds, } \\
\text { Line } 1 \text {, } \\
\text { sexual } \\
\text { maturity } \\
\text { at } 214.8 \\
\text { days }\end{array}$ & $\begin{array}{c}10 \text { birds, } \\
\text { Line } 3, \\
\text { sexual } \\
\text { maturity } \\
\text { at } 163.5 \\
\text { days }\end{array}$ & $\begin{array}{l}3 \text { birds, } \\
\text { Line 5, } \\
\text { sexual } \\
\text { maturity } \\
\text { at 178 } \\
\text { days }\end{array}$ & $\begin{array}{c}3 \text { birds, } \\
\text { Line 5, } \\
\text { sexual } \\
\text { maturity } \\
\text { at 194.3 } \\
\text { days }\end{array}$ & $\begin{array}{l}6 \text { birds, } \\
\text { Line 6, } \\
\text { sexual } \\
\text { maturity } \\
\text { at } 211.2 \\
\text { days }\end{array}$ & $\begin{array}{l}8 \text { birds, } \\
\text { Line 6,, } \\
\text { sexual } \\
\text { maturity } \\
\text { at } 231.9 \\
\text { days }\end{array}$ \\
\hline January........ & 19.79 & 20.35 & 18.91 & 19.11 & 18.37 & 18.50 \\
\hline February..... & 20.02 & 20.28 & 19.24 & 19.70 & 19.28 & 19.24 \\
\hline March.. & 20.29 & 20.45 & 19.97 & 20.34 & 18.95 & 19.18 \\
\hline April. . & 21.00 & 19.75 & 20.15 & 19.81 & 19.29 & 19.30 \\
\hline May... & 20.80 & 20.38 & 21.50 & 19.49 & 19.68 & 19.53 \\
\hline June......... & 21.47 & 20.54 & 19.99 & 20.45 & 18.64 & 20.33 \\
\hline July.......... & 21.89 & 20.74 & 20.25 & 20.56 & 19.42 & 20.53 \\
\hline August................ & 21.87 & 16.37 & 16.20 & 20.43 & 20.32 & 20.06 \\
\hline September............ & 21.44 & 17.34 & 18.08 & 16.79 & 19.14 & 18.56 \\
\hline October................ & 19.14 & 18.31 & 18.09 & 17.91 & 18.13 & 17.77 \\
\hline November.... & 18.80 & 18.76 & 18.35 & 18.32 & 17.61 & 17.52 \\
\hline December............ & 19.52 & 19.35 & 18.61 & 18.49 & 18.14 & 18.85 \\
\hline
\end{tabular}

\section{Experimental Results}

In tables 1 to 3 the monthly average egg size, expressed in ounces per dozen eggs, is shown for the different breeds under study. The breeds dif- 
fered among themselves in respect to egg weight. A similar breed difference had already been reported by González Chapel (2). Eggs from the New Hampshire and White Leghorn birds weighed more than those of the crossbred birds.

In all breeds represented in more than one month the egg size increased progressively during the first month of laying according to the month in which laying started. In the New Hampshire breed the first-month egg weight was lowest in August and greater in January. In the other breeds it

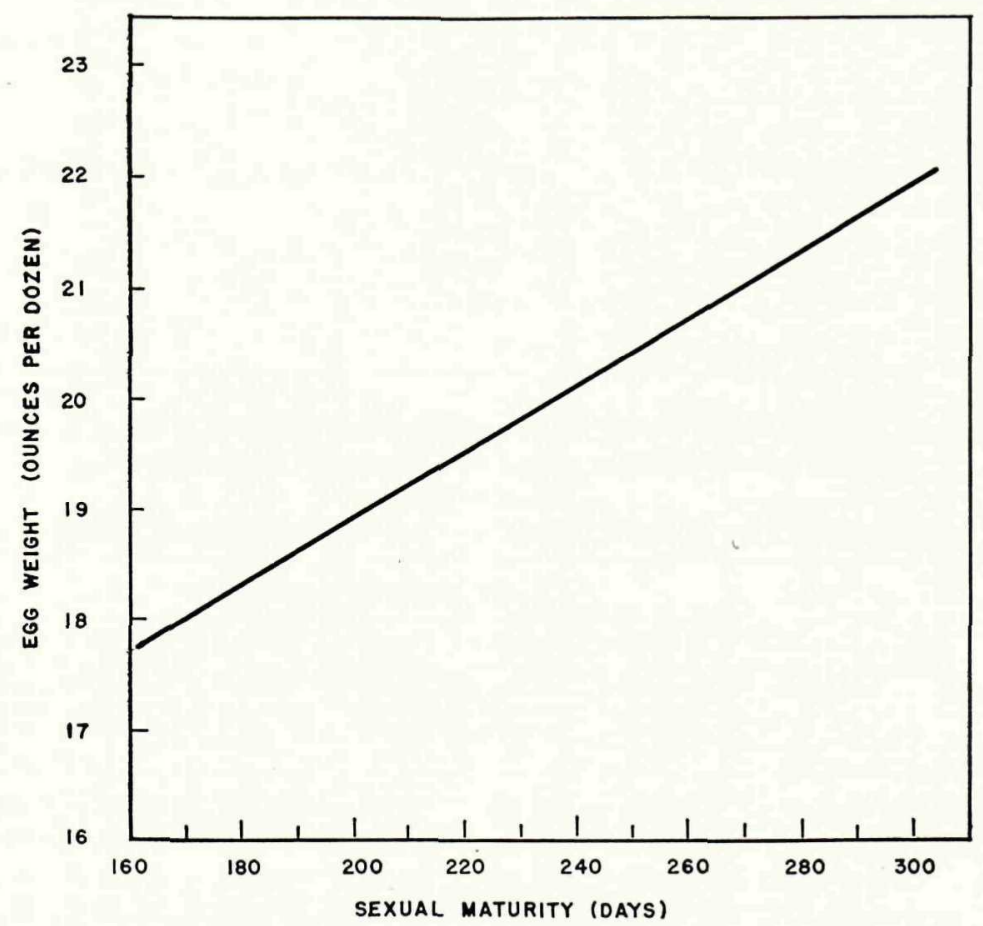

Frg. 1.-Regression of first-month egg size on sexual maturity for New Hampshire birds.

was lowest in August and greater in the subsequent months. This was attributable to the sexual maturity of the birds. The regression of the first-month egg weight on the sexual maturity of the birds is shown in figure 1.

González Chapel (2) found significant correlations between sexual maturity and egg weight in New Hampshire, White Leghorn, and Native birds. He concluded that these correlations probably occurred because of the larger body size of the late-maturing birds at the time of laying their first 
egg. Jull (5) says that the earlier in life laying commences, the smaller the size of the birds, on the average, and the smaller the size of the egg, on the average.

The curves of egg size for all the breeds are shown in figure 2 .

The egg size increased progressively during the first months of laying and maximum egg size was attained from May to June in most of the groups. In the summer months there was a definite downward drop in egg weight. According to Jull (5), there is an increase in size or weight of eggs laid during the first laying year in most flocks in the United States from the time that laying commences up to the spring of the year. Maximum egg

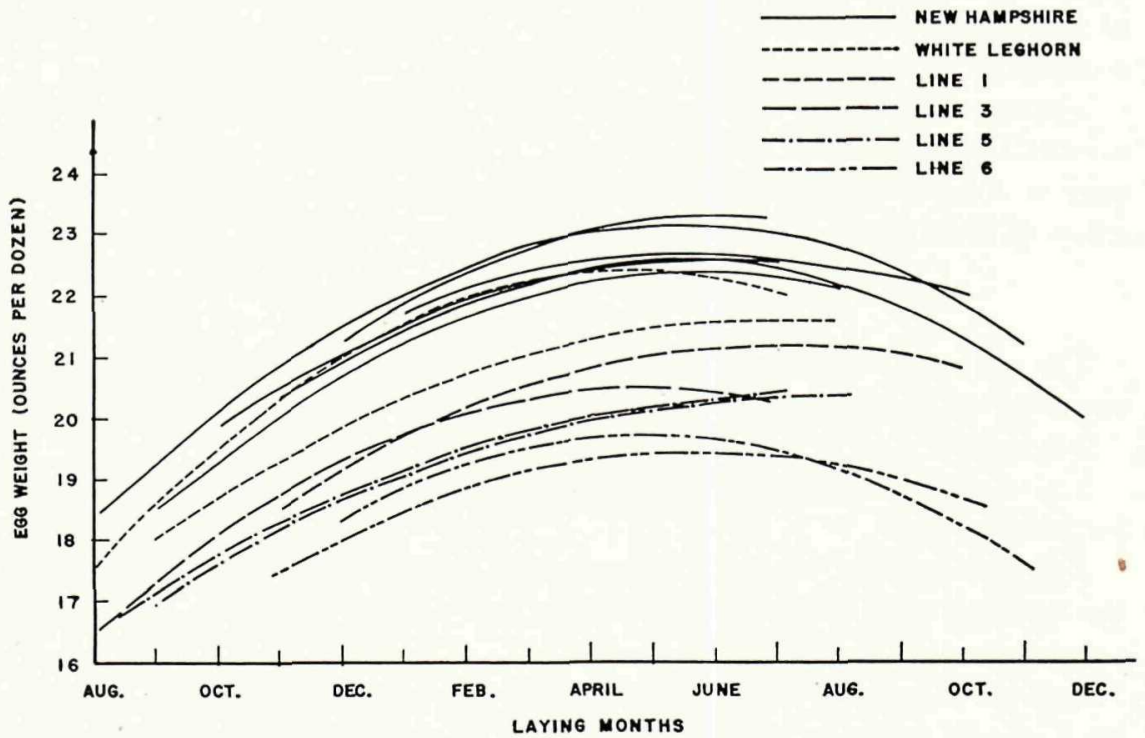

FIG. 2.-Egg size during the first laying year for different breeds and crossbreds as indicated.

weight is usually attained in February or March; during the late spring and the summer there is often a slight relative decline followed by an increase at the close of the first-laying year.

The shape of the curve was the same for most of the groups within each breed, regardless of the month in which laying started. Although the breeds differed between themselves in respect to egg size, the shape of the curve was also similar for most of them.

In some of the groups of the birds, especially in the New Hampshire breed, egg size tended to decline from March to April and to increase again from April to May. But this slight tendency was smoothed out in the statistical curve. 


\section{Discussion}

The results of this study seem to agree with the findings of Warren et al (9) at the Kansas State College. They studied groups of birds under a controlled environment. They concluded the evidence was clean-cut that egg size was depressed by temperature in the hotter summers. If the hens were not subjected to high summer temperatures, egg size increased throughout the entire first laying year. They also concluded that a constant temperature of $65^{\circ} \mathrm{F}$. is too high for maximum egg size.

The warmer temperature in Puerto Rico, as compared to that of the United States, causes the egg size to increase more slowly at the beginning of the laying year, but with the higher summer temperature, egg size decreases faster toward the end of the laying year.

The egg size of the New Hampshires and the White Leghorns was over-all smaller than is commonly seen in similar flocks in the United States. However, it is not clear whether this smaller egg size is a result of a depressive effect of high temperature or is attributable to the breeding of the birds.

\section{SUMmary}

The curve of the egg size (in ounces per dozen eggs) for the first laying year was studied in a group of 206 pullets of different breeds and crossbreds.

Regression studies were made of the average monthly egg size.

The early-maturing pullets started by laying smaller eggs than the latematuring pullets.

- The observations made on the curves of the egg size seems to agree with the findings of Warren et al (9) in respect to the depressive effect of high temperature on egg weight.

Egg size increased progressively during the first months of laying, reaching a maximum from May to June. The high summer temperatures caused it to decrease rapidly toward the end of the laying year.

\section{Literature Cited}

1. Bennion, N. L. and Warren, D. C., Temperature and its effect on egg size in the domestic fowl, Poul. Sci. 12 69-82, 1933.

2. González Chapel, A., Comparative performance of the Native Puerto Rican fowl, the White Leghorn, the New Hampshire, and crosses between them, Jour. Agric. Univ. P. R. 31, 4 265-302, 1947.

3. González Chapel, A. and Rojas, M., Influence of time of hatching on sexual maturity of pullets in Puerto Rico, Jour. Agric. Univ. P. R. 35(3) July 1951.

4. Harris, M. F., La temperatura de Puerto Rico, Dept. de Agric. y Comercio de Puerto Rico, Almanaque Agrícola 75-82, 1947.

5. Jull, M. A., Poultry Breeding, 2nd ed., John Wiley and Sons, New York, N. Y., pp. 347, 353, 1946. 
6. Lorenz, F. W. and Almquist, H. J., Seasonal variations in egg quality, Poul. Sci., 15 14-18, 1936.

7. Snedecor, G. W., Statistical Methods, 4th ed., Iowa State College Press, Ames, Iowa, 1946.

8. Warren, D. C., Effect of temperature on size of eggs from pullets in different latitudes, Jour. Agr. Res. 59 441-452, 1939.

9. Warren, D. C., Conrad, R., Schumacher, A. E., and Anery, T. B., Effects of fluctuating environment on laying hens; Kansas State College, Tech. Bull. 68, 1950. 